\title{
SOIL ATTRIBUTES AND WHEAT PERFORMANCE IN A GEOREFERENCED SEED PRODUCTION FIELD
}

\author{
Gizele I. Gadotti ${ }^{1}$, Marciabela F. Corrêa ${ }^{2}$, Renan Navroski ${ }^{2}$, Ariele P. Nadal ${ }^{2}$, Luis O. B. Schuch ${ }^{2}$ \\ ${ }^{1 *}$ Corresponding author. Universidade Federal de Pelotas/ Pelotas - RS, Brasil. E-mail: gizeleingrid@ gmail.com
}

\section{KEYWORDS}

precision agriculture, fertility, seed quality, Triticum aestivum L., spatial variability.

\begin{abstract}
The aim of this research was to study the linear correlations and spatial distribution between soil attributes and productivity and physiological quality of wheat seeds. Soil samples were collected at georeferenced points in an area of 41 ha with a rectangular grid of $100 \times 100 \mathrm{~m}$ to determine soil fertility. Grain productivity, number of ears $\mathrm{m}^{-2}$, protein content, and physiological seed quality were assessed. The results were submitted to Pearson's correlation analysis, descriptive statistics, and geostatistics. Phosphorus content presented a high spatial variability, with a coefficient of variation of $97.79 \%$. Protein content, number of ears, and SMP index presented low values of coefficient of variation, indicating their low spatial variability. Physiological seed quality was not correlated with soil attributes. Wheat productivity showed a strong correlation between calcium and soil organic matter contents, as verified by analyzing the spatial distribution maps. The analysis of the spatial distribution maps of soil nutrients is a tool that can contribute to farmers' decision making in the management of crop fertilization aiming at increasing productivity.
\end{abstract}

\section{INTRODUCTION}

Precision agriculture is a set of tools to help farmers to manage field processes using a series of information about the area, such as digital models and satellite images for soil fertility and productivity. This tool aims at managing soil, plant, and environmental spatial and temporal variability to achieve a high productivity and improved input-use efficiency, reducing production costs (Luz et al., 2013).

The collection of georeferenced soil samples allows spatializing soil chemical attributes with geostatistics tools, frequently used to identify zones with chemical restrictions that may be limiting the yield. However, the characterization and spatialization of soil physical attributes in commercial areas have been little used due to the inherent difficulties for collecting and analyzing a large number of samples (Amado et al., 2009).

Soil compaction reduces root growth due to an increase in soil penetration resistance, which can lead to crop productivity losses related to the restriction of water and nutrient to plant roots (Bergamin et al., 2010).

Soil chemical attributes have a great spatial and temporal variability, which can be attributed to intrinsic and extrinsic factors, i.e. pedogenetic factors of soil and factors related to its management. This variability in the soil may have a high correlation with physiological seed quality since nutrients play specific functions in plants and in their metabolic processes, which can be affected by nutrient content and its availability in the soil. However, working with the correlation between soil nutrient contents and physiological quality of soybean seeds, Mondo et al. (2012) did not find a significant correlation between the contents of phosphorus, potassium, calcium, magnesium, and $\mathrm{pH}$ with germination, first germination count, and accelerated aging.

The study of the correlation between soil attributes and plants is important to establish and quantify soil attributes that have a greater influence on crop productivity, as mentioned in several studies (Amado et al., 2009; Rodrigues et al., 2012; Santi et al., 2012; Mattioni et al., 2013; Gazolla-Neto et al., 2016). This study fits as a way to manage a field of seed production since it is a crop with a high added value and needs a special attention to obtain seeds with a high physiological quality.

In this context, the aim of this research was to study the linear correlations and spatial distribution between soil attributes and productivity and physiological quality of wheat seeds by using precision agriculture techniques.

\footnotetext{
${ }^{2}$ Universidade Federal de Pelotas/ Pelotas - RS, Brasil. 


\section{MATERIAL AND METHODS}

This study was carried out in an area of 41 ha of wheat seed production of the company Granello Sementes in Lavras do Sul, RS, Brazil $\left(30^{\circ} 43^{\prime} 18.6^{\prime \prime} \mathrm{S}\right.$ and $53^{\circ} 56^{\prime} 44.4^{\prime \prime} \mathrm{W}$ ), in the 2013/2013 season. The relief of the area is little wavy, with soil classified as a Neossolo Litólico eutrófico (EMBRAPA, 2013) (Lithic Quartzipsamment, USDA Soil Taxonomy). According to Köppen classification, regional climate is type $\mathrm{Cfa}$.
From the outline map of the area, a sampling grid was elaborated with sampling points spatialized in $100 \times$ 100 meters, characterizing one point per hectare and totaling 41 collection points. For determining soil and seed attributes, four subsamples were collected, being one subsample at the georeferenced point (central sampling point) and the others collected at points equidistant around the point in a 15-m radius (Figure 1).

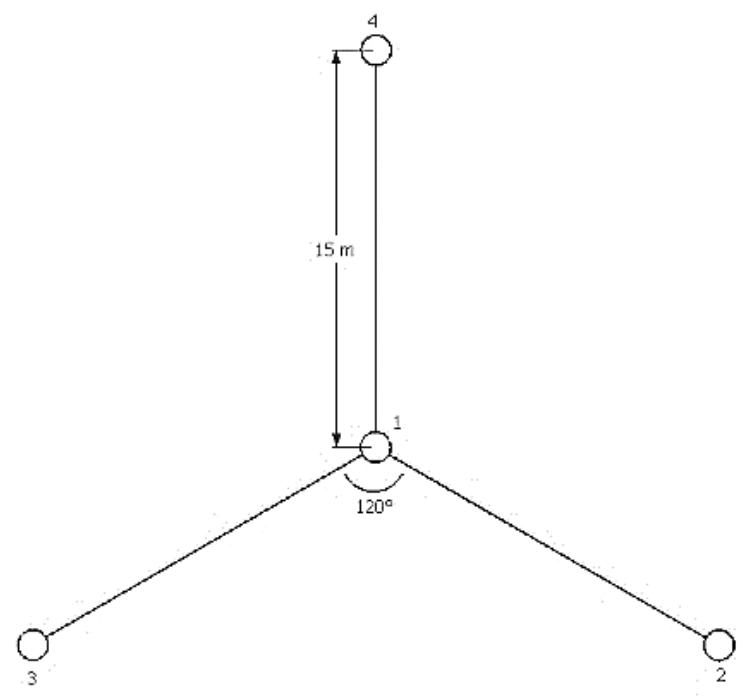

FIGURE 1. Diagram of demarcation of the central sampling point and sampling points equidistant within the production field, 2013 season.

The central sampling points were defined based on the systematic sampling method, following a regular sampling grid, where points are marked along a predefined course and based on the field outlines (Mattioni et al., 2011). Samples were collected in the interrow, at a depth of $0.00-0.10 \mathrm{~m}$, as indicated by CQFS (2016).

This study was carried out in a consolidated notillage area, in which the production system is characterized by the succession of the following crops: winter crop (2012) - ryegrass pasture; summer crop (2012/2013) - soybean; winter crop (2013) - wheat; summer crop (2013/2014) -soybean. This study assessed wheat crop (2013).

Sowing was carried out on June 14, 2013, to reach a population of 300 plants $\mathrm{m}^{-2}$. In the base fertilization, $280 \mathrm{~kg} \mathrm{ha}^{-1}$ of the NPK formula 5-20-20 was used according to soil analysis. Topdressing nitrogen fertilization was fractionated into two applications, one at the tillering stage (90 kg ha ${ }^{-1}$ urea) and other at stem elongation stage (190 $\mathrm{kg} \mathrm{ha}^{-1}$ urea). A fertilization with potassium chloride $\left(100 \mathrm{~kg} \mathrm{ha}^{-1}\right)$ was also performed at the stem elongation stage. The phenological scale is in accordance with Rodrigues et al. (2011).

The determination of soil mechanical penetration resistance was carried out by means of a Falker PLG 1020 electronic penetrometer. The measurement was performed at each central point of the sampling grid and at the three lateral points. The layer of 0.00 to $0.40 \mathrm{~m}$ was analyzed on November 04, 2013, and the results were presented in layers of $0.00-0.10,0.11-0.20,0.21-0.30$, and $0.31-0.40 \mathrm{~m}$.

The assessment of soil chemical attributes (calcium, magnesium, phosphorus, potassium, organic matter (OM), cation exchange capacity (CEC), SMP index, aluminum, sulfur, sand, and clay) was performed after wheat harvesting according to the indications of the Comissão de Química e Fertilidade do Solo (CQFS, 2016).

In order to determine the productivity and physiological seed quality, plants were collected in four 1$\mathrm{m}^{2}$ subsamples at each point of the sampling grid, as described previously, forming an average sample of the point.

Physiological seed quality was assessed by the following tests:

Germination (G): conducted with eight replications of 50 seeds. Sowing was conducted on paper substrates previously moistened with distilled water in the proportion of 2.5 times the weight of the dry paper and maintained in a germinator at $20^{\circ} \mathrm{C}$. The assessments were carried out at four and eight days after sowing, according to the Rules for Seed Testing (Brasil, 2009) and the results were expressed as a percentage of normal seedlings.

First germination count (FGC): conducted together with the germination test and assessment at four days after sowing.

Electrical conductivity (EC): performed by the mass system according to the methodology proposed by the vigor committee of the Association of Official Seed Analysts, described by Marcos Filho et al. (1987). Four samples of 50 seeds, previously weighed in a $0.0001 \mathrm{~g}$ precision scale, were placed in plastic cups containing 50 $\mathrm{mL}$ deionized and distilled water. The cups were maintained in an environment at $25{ }^{\circ} \mathrm{C}$ and readings were performed after soaking for 24 hours. The obtained average values were expressed in $\mu \mathrm{S} \mathrm{cm}^{-1} \mathrm{~g}$ of seeds ${ }^{-1}$. The test was performed on February 25 and 26, 2014. 
Accelerated aging (AA): performed in Gerbox boxes with a metallic screen. A volume of $40 \mathrm{~mL}$ distilled water was added to the bottom of each box and seeds were evenly distributed on the screen in a single layer. Subsequently, these boxes were capped and conditioned in a BOD incubator at $41^{\circ} \mathrm{C}$ for 72 hours. After this period, seeds were submitted to the germination test (Delouche \& Baskin, 1973).

Field seedling emergence (SE): carried out with four subsamples of 50 seeds for each sampling point, distributed in a $1.0 \mathrm{~m}$ long furrow and a depth of $2.5 \mathrm{~cm}$. Sowing was carried out in soil beds at the time recommended for cultivation. The emerged seedling count was performed at 14 days after sowing.

Protein content: performed by nuclear magnetic resonance spectrometry (RMN), according to OSU (2017).

Number of ears: obtained by counting the ears in the four subsamples of one square meter and the result was expressed in ears $\mathrm{m}^{-2}$.

Productivity: the ears in the four subsamples of one square meter at each sampling point were harvested and threshed, moisture corrected to $13 \%$, and the result expressed in $\mathrm{kg} \mathrm{ha}^{-1}$.

Pearson's linear correlation coefficients were determined using the WINSTAT statistical program (Machado \& Conceição, 2007). Spatial variability was analyzed using the classification criterion for coefficient of variation (CV) proposed by Wilding \& Dress (1983), which defines as low the variability of attributes with a CV value lower than $15 \%$, moderate the variability with a $\mathrm{CV}$ between 15 and $35 \%$, and high the variability with a CV value higher than $35 \%$.

Digital models were elaborated by means of the software Sistema Agropecuário CR - Campeiro 7 (Giotto et al., 2004). Kriging was the geostatistical method of interpolation used for elaborating the digital models. Parameter estimation was carried out by the maximum likelihood method.

Pearson's linear correlation of soil and wheat attributes is represented by values ranging from -1 to +1 , so that according to the criterion proposed by Dancey \& Reidy (2013), positive or negative values below of 0.3 indicate a low correlation, between 0.3 and 0.7 indicate a moderate correlation, and above 0.7 indicate a strong correlation.

The degree of spatial dependence (DSD) of semivariograms was assessed considering the intervals proposed by Cambardella et al. (1994): DSD < 25\% strong spatial dependence; $25 \%<\mathrm{DSD}<75 \%$ - moderate spatial dependence; and DSD >75\% - weak spatial dependence.

\section{RESULTS AND DISCUSSION}

Table 1 shows the descriptive statistics of soil attributes. Phosphorus was the soil attribute that presented the highest spatial variability, with a CV of $97.79 \%$, according to the spatial variability criterion proposed by Wilding \& Dress (1983). Alves et al. (2014) and GazollaNeto et al. (2016) found similar results for phosphorus, which presented coefficients of variation of 95.35 and $102 \%$, respectively.

This high spatial variability of phosphorus could be explained by its low mobility in the soil. Thus, its superficial accumulation occurs in no-tillage areas, caused by the non-disturbance of soil and fertilization of the row, hindering its loss by erosion.

Calcium, magnesium, and organic matter presented a moderate spatial variability (Table 1). Mondo et al. (2012) found similar results, with organic matter and magnesium presenting a moderate variability, but with a low variability of calcium.

Table 1 shows a strong degree of spatial dependence for $\mathrm{Ca}, \mathrm{OM}, \mathrm{S}$, sand and clay contents, CEC, and SMP index. According to Cambardella et al. (1994), attributes that have a strong spatial dependence are more influenced by the intrinsic soil properties such as texture and mineralogy, while those with a week spatial dependence are more influenced by external factors such as fertilizer application, soil tillage, and cultivation, i.e. soil management. The other variables presented a moderate spatial dependence, corroborating the results found by Gazolla-Neto et al. (2016).

The range is the main parameter provided by geostatistics, which is the distance at which a variable signals spatial continuity and, from this distance, the spatial behavior of the variable becomes totally random (Lemos Filho et al., 2008). On the other hand, determinations performed at lower distances are correlated to each other, allowing interpolations for smaller spacing than those sampled (Andriotti, 2013). According to the data analysis observed in Tables 1 and 2, range values of the spatial dependence varied from 200 to $600 \mathrm{~m}$. Therefore, the sampling grid was adequate since it was smaller than $200 \mathrm{~m}$. In general, soil attributes have larger ranges, while plant attributes present smaller ranges. Table 1 shows the soil chemical attributes, classified according to CQFS (2016). 
TABLE 1. Statistical and geostatistical parameters of soil attributes in the 2013 season. Lavras do Sul - RS (Brazil).

\begin{tabular}{|c|c|c|c|c|c|c|c|c|c|}
\hline \multirow[t]{2}{*}{ Variable } & \multicolumn{2}{|c|}{ Value } & \multirow[t]{2}{*}{ Mean } & \multirow[t]{2}{*}{ Classification* } & \multirow[b]{2}{*}{ Variation } & Coefficient & \multirow[b]{2}{*}{ Kurtosis } & \multirow[t]{2}{*}{ DSD } & \multirow[t]{2}{*}{ Range } \\
\hline & $\overline{\text { Min }}$ & Max & & & & Skewness & & & \\
\hline $\mathrm{Ca}$ & 3.8 & 16.5 & 10.4 & High & 22.97 & -0.37 & 0.82 & 22.28 & 500 \\
\hline $\mathrm{Mg}$ & 1.1 & 5.7 & 3.7 & High & 24.99 & -0.14 & 0.57 & 36.16 & 500 \\
\hline $\mathrm{P}$ & 4.1 & 50.7 & 16.8 & High & 97.79 & 1.39 & 0.28 & 33.76 & 400 \\
\hline $\mathrm{K}$ & 63 & 197 & 96.3 & High & 28.46 & 1.56 & 3.62 & 31.89 & 400 \\
\hline $\mathrm{OM}$ & 1.9 & 4.2 & 3.1 & Medium & 15.86 & -0.10 & -0.08 & 21.48 & 500 \\
\hline $\mathrm{CEC} \mathrm{pH} 7$ & 2.1 & 34.7 & 22.1 & High & 26.01 & -0.91 & 2.50 & 24.65 & 500 \\
\hline $\mathrm{pH}$ & 4.8 & 5.5 & 5.24 & Low & 2.56 & -0.82 & 1.79 & 29.99 & 600 \\
\hline $\mathrm{S}$ & 13.1 & 30.7 & 18.6 & High & 24.17 & 1.02 & 0.05 & 11.53 & 500 \\
\hline $\mathrm{Zn}$ & 1.3 & 5.5 & 3.5 & High & 30.97 & 0.07 & -0.70 & 29.76 & 500 \\
\hline $\mathrm{Al}$ & 0.1 & 0.7 & 0.2 & - & 52.45 & 3.04 & 14.38 & 27.21 & 500 \\
\hline SMP index & 5.1 & 5.9 & 5.5 & - & 3.85 & -0.10 & -1.04 & 14.68 & 500 \\
\hline Sand & 36.7 & 66.6 & 49.6 & - & 12.8 & 0.36 & 0.02 & 20.22 & 500 \\
\hline Silt & 9.9 & 20.9 & 15.5 & - & 15.27 & -0.33 & 0.01 & 36.68 & 500 \\
\hline Clay & 21.9 & 44.9 & 34.9 & - & 17.51 & 0.06 & -0.91 & 15.47 & 500 \\
\hline $\begin{array}{c}\text { SPR 0.0- } \\
0.10\end{array}$ & 0.353 & 1.126 & 0.664 & - & 30.05 & 0.49 & -0.45 & 26.78 & 500 \\
\hline $\begin{array}{c}\text { SPR 0.11- } \\
0.20\end{array}$ & 0.857 & 2.382 & 1.405 & - & 21.38 & 1.48 & 3.49 & 31.91 & 500 \\
\hline $\begin{array}{c}\text { SPR 0.21- } \\
0.30\end{array}$ & 1.049 & 2.188 & 1.357 & - & 17.21 & 1.87 & 5.15 & 31.28 & 500 \\
\hline $\begin{array}{c}\text { SPR 0.31- } \\
0.40\end{array}$ & 1.140 & 2.328 & 1.654 & - & 16.93 & 0.47 & -0.12 & 46.63 & 300 \\
\hline
\end{tabular}

*According to CQFS (2016); DSD = degree of spatial dependence; SPR = soil penetration resistance (MPa).

Regarding the crop attributes (Table 2), the descriptive statistics showed for productivity a minimum value of $2739 \mathrm{~kg} \mathrm{ha}^{-1}$, maximum of $5378 \mathrm{~kg} \mathrm{ha}^{-1}$, and an amplitude of $2639 \mathrm{~kg} \mathrm{ha}^{-1}$, i.e. a potential to produce 5378 $\mathrm{kg} \mathrm{ha}^{-1}$, but with an average of $4243 \mathrm{~kg} \mathrm{ha}^{-1}$. Therefore, it is necessary to observe and correct the factors that most influence wheat productivity. Productivity presented a CV of $12.44 \%$, which shows a low spatial variability in the study area. The number of ears presented minimum, maximum, and average values of 333.0, 479.75, and 402.571 ears $\mathrm{m}^{-2}$, respectively, with a $\mathrm{CV}$ of $10.11 \%$, which means a low spatial variability (Table 2).
In addition, protein content, number of ears $\mathrm{m}^{-2}$, and SMP index presented low CV values, indicating a low spatial variability.

The attributes of physiological seed quality presented a low spatial variability (Table 2 ). The average germination was $95 \%$, with values ranging from 89 to $98 \%$ and a $\mathrm{CV}$ of $1.75 \%$, which is considered as low. Germination, first germination count, and field seedling emergence presented an amplitude between the minimum and maximum values of 9,29 , and $37 \%$, respectively. The different treatments during cultivation may contribute to the production of seeds with a high physiological quality.

TABLE 2. Statistical and geostatistical parameters of wheat plants and seed attributes in the 2013 season. Lavras do Sul - RS (Brazil).

\begin{tabular}{|c|c|c|c|c|c|c|c|c|}
\hline \multirow[t]{2}{*}{ Variable } & \multicolumn{2}{|c|}{ Value } & \multirow[t]{2}{*}{ Mean } & \multicolumn{3}{|c|}{ Coefficient } & \multirow[t]{2}{*}{ DSD } & \multirow[t]{2}{*}{ Range } \\
\hline & Min & Max & & Variation & Skewness & Kurtosis & & \\
\hline Prod. & 2,739 & 5,378 & 4,243 & 12.44 & -0.58 & 1.19 & 56.32 & 200 \\
\hline NE & 333 & 479 & 402 & 3.68 & 0.13 & -0.93 & 38.79 & 400 \\
\hline Prot. & 13.3 & 15.6 & 14.5 & 3.68 & -0.24 & 0.03 & 44.12 & 500 \\
\hline G & 89 & 98 & 95 & 1.75 & -1.40 & 3.44 & 50.76 & 200 \\
\hline FGC & 66 & 95 & 83 & 8.12 & -0.46 & -0.16 & 33.6 & 500 \\
\hline AA & 90 & 98 & 95 & 1.86 & -0.87 & 1.01 & 42.52 & 400 \\
\hline SE & 60 & 97 & 83 & 9.99 & -0.44 & 0.23 & 51.3 & 200 \\
\hline $\mathrm{EC}$ & 15 & 30 & 23 & 14.93 & -0.29 & -0.32 & 45.3 & 300 \\
\hline
\end{tabular}

Prod. = productivity; $\mathrm{NE}=$ number of ears Prot. = protein $\mathrm{G}=$ germination $; \mathrm{FGC}=$ first germination count $\mathrm{AA}=$ accelerated aging; $\mathrm{SE}=$ field seedling emergence; $\mathrm{EC}=$ electrical conductivity; $\mathrm{DSD}=$ degree of spatial dependence. 
Table 3 shows the results of Pearson's linear correlation of soil and wheat attributes. Among soil chemical attributes, the correlation between calcium and magnesium, organic matter, CEC pH 7, SMP index, sand, and clay was strong, while between calcium and phosphorus, aluminum, and sulfur it was moderate.

Soil attributes that best correlated with wheat productivity were calcium, magnesium, organic matter, and CEC. Rodrigues et al. (2012) obtained similar results with corn under the no-tillage system and by Kramer et al. (2014) with wheat. Wheat productivity showed a moderate correlation with magnesium, phosphorus, cation exchange capacity, SMP index, aluminum, sulfur, sand, and clay. Kramer et al. (2014) also observed a correlation between wheat productivity and calcium and magnesium content in the soil.

Productivity presented a negative correlation with sand and aluminum contents and a positive correlation with clay content, corroborating the results found by Rodrigues et al. (2012) in a study conducted with corn under no-tillage system. The negative correlation between productivity and aluminum content shows that high aluminum contents decrease productivity. The most evident symptom of the harmful effect of aluminum is a reduction in root growth of sensitive plants, preventing the plant from obtaining water and nutrients in points of higher depths due to its superficial rooting (Miguel et al., 2010).
Wheat productivity showed a strong correlation between calcium and soil organic matter, as shown in the spatial distribution maps (Figure 2). This correlation between productivity and organic matter shows its important role in improving soil structure and porosity, contributing to an increased productivity. Moreover, productivity presented a negative correlation with soil penetration resistance in the layers of $0.0-0.10$ and $0.11-$ $0.20 \mathrm{~m}$, i.e. the higher the soil penetration resistance is, the lower the productivity. In fact, an increase in soil compaction reduces root growth due to an increase in soil penetration resistance, which can lead to crop productivity losses due to a restriction of water and nutrient to plant roots (Bergamin et al., 2010).

The number of ears $\mathrm{m}^{-2}$ presented a moderate correlation with calcium, magnesium, organic matter, sulfur, zinc, sand, CEC, and SMP index. Regarding physiological quality of wheat seeds, germination, accelerated aging, and field emergence tests presented no correlation with soil attributes. Similarly, Gazolla et al. (2015) did not observe a correlation between soil attributes and physiological quality of soybean seeds. First germination count test presented a moderate correlation with potassium content and week with clay content. In addition, electrical conductivity test presented a moderate correlation with potassium, organic matter, sand, clay, CEC, SMP index, and $\mathrm{pH}$ (Table 3). 
TABLE 3. Pearson's correlation coefficients among soil attributes, wheat attributes, protein content, and physiological attributes of seed quality.

\begin{tabular}{|c|c|c|c|c|c|c|c|c|c|c|c|c|c|c|c|c|c|c|c|c|c|c|}
\hline & $\mathrm{Mg}$ & $P$ & $\mathrm{~K}$ & $\mathrm{OM}$ & $\mathrm{CEC}_{\mathrm{pH} 7}$ & SMP & $\mathrm{Al}$ & $\mathrm{S}$ & Sand & Clay & $\begin{array}{c}\text { SPR } \\
0.0-0.10\end{array}$ & $\begin{array}{c}\text { SPR } \\
0.11- \\
0.20\end{array}$ & $\begin{array}{c}\text { SPR } \\
0.21- \\
0.30 \\
\end{array}$ & $\begin{array}{c}\text { SPR } \\
0.31- \\
0.40 \\
\end{array}$ & Prod. & $\mathrm{NE}$ & Prot. & G & FGC & $\overline{A A}$ & SE & $\mathrm{EC}$ \\
\hline $\mathrm{Ca}$ & $0.844^{* *}$ & $0.442^{* *}$ & $-0.138^{\mathrm{Ns}}$ & $0.932^{* *}$ & $0.831^{* *}$ & $-0.717^{* *}$ & $-0.437^{* *}$ & $0.663^{* *}$ & $-0.905^{* *}$ & $0.826^{* *}$ & $-0.677^{* *}$ & $-0.601^{* *}$ & $-0.606^{* *}$ & $-0.453^{* *}$ & $0.722^{* *}$ & $0.485^{* *}$ & $-0.094^{\mathrm{NS}}$ & $-0.072^{\mathrm{NS}}$ & $-0.284^{\mathrm{NS}}$ & $-0.093^{\mathrm{NS}}$ & $0.067^{\mathrm{Ns}}$ & $-0.284^{\mathrm{NS}}$ \\
\hline $\mathrm{Mg}$ & & $0.239^{\mathrm{Ns}}$ & $0.033^{\mathrm{Ns}}$ & $0.786^{* *}$ & $0.707^{* *}$ & $-0.489 * *$ & $-0.475^{* *}$ & $0.586^{* *}$ & $-0.789 * *$ & $0.726^{* *}$ & $-0.555^{* *}$ & $-0.553^{* *}$ & $-0.534^{* *}$ & $-0.290^{\mathrm{NS}}$ & $0.606^{* *}$ & $0.451^{* *}$ & $0.058^{\mathrm{NS}}$ & $-0.119^{\mathrm{Ns}}$ & $-0.276^{\mathrm{Ns}}$ & $-0.072^{\mathrm{Ns}}$ & $0.059^{\mathrm{Ns}}$ & $-0.206^{\mathrm{NS}}$ \\
\hline $\mathrm{P}$ & & & $0.088^{\mathrm{NS}}$ & $0.496^{* *}$ & $0.492^{* *}$ & $-0.598^{* *}$ & $0.028^{\mathrm{NS}}$ & $0.488^{* *}$ & $-0.423^{* *}$ & $0.496^{* *}$ & $-0.071^{\mathrm{NS}}$ & $0.055^{\mathrm{NS}}$ & $0.028^{\mathrm{Ns}}$ & $-0.004^{\mathrm{NS}}$ & $0.400^{* *}$ & $0.223^{\mathrm{NS}}$ & $0.026^{\mathrm{NS}}$ & $-0.156^{\mathrm{Ns}}$ & $-0.279^{\mathrm{NS}}$ & $-0.287^{\mathrm{Ns}}$ & $0.026^{\mathrm{Ns}}$ & $0.008^{\mathrm{NS}}$ \\
\hline K & & & & $-0.028^{\mathrm{Ns}}$ & $-0.022^{\mathrm{Ns}}$ & $0.021^{\mathrm{Ns}}$ & $0.119^{\mathrm{Ns}}$ & $0.263^{\mathrm{NS}}$ & $0.057^{\mathrm{Ns}}$ & $0.040^{\mathrm{Ns}}$ & $0.282^{\mathrm{Ns}}$ & $0.248^{\mathrm{Ns}}$ & $0.233^{\mathrm{Ns}}$ & $0.379 *$ & $-0.025^{\mathrm{Ns}}$ & $0.008^{\mathrm{Ns}}$ & $0.197^{\mathrm{Ns}}$ & $-0.279^{\mathrm{Ns}}$ & $-0.414^{* *}$ & $-0.194^{\mathrm{Ns}}$ & $0.124^{\mathrm{Ns}}$ & $-0.329 *$ \\
\hline $\mathrm{OM}$ & & & & & $0.818^{* *}$ & $-0.773^{* *}$ & $-0.316^{*}$ & $0.724^{* *}$ & $-0.891^{* *}$ & $0.839 * *$ & $-0.614^{* *}$ & $-0.483^{* *}$ & $-0.489 * *$ & $-0.397^{*}$ & $0.716^{* *}$ & $0.478^{* *}$ & $-0.007^{\mathrm{Ns}}$ & $-0.138^{\mathrm{NS}}$ & $-0.121^{\mathrm{NS}}$ & $-0.128^{\mathrm{NS}}$ & $0.085^{\mathrm{Ns}}$ & $-0.380^{*}$ \\
\hline $\mathrm{CEC}_{\mathrm{pH} 7}$ & & & & & & $-0.713^{* *}$ & $-0.231^{\mathrm{NS}}$ & $0.663^{* *}$ & $-0.819 * *$ & $0.819 * *$ & $-0.377^{*}$ & $-0.269^{\mathrm{Ns}}$ & $-0.314^{*}$ & $-0.196^{\mathrm{Ns}}$ & $0.629 * *$ & $0.449^{* *}$ & $0.236^{\mathrm{NS}}$ & $-0.136^{\mathrm{Ns}}$ & $-0.303^{\mathrm{NS}}$ & $-0.112^{\mathrm{NS}}$ & $0.037^{\mathrm{Ns}}$ & $-0.317^{*}$ \\
\hline SMP & & & & & & & $-0.102^{\mathrm{Ns}}$ & $-0.774^{* *}$ & $0.786^{* *}$ & $-0.832^{* *}$ & $0.407^{* *}$ & $0.244^{\mathrm{Ns}}$ & $0.225^{\mathrm{NS}}$ & $0.246^{\mathrm{Ns}}$ & $0.558^{* *}$ & $-0.396^{*}$ & $-0.100^{\mathrm{Ns}}$ & $0.230^{\mathrm{NS}}$ & $0.459 * *$ & $0.191^{\mathrm{NS}}$ & $-0.115^{\mathrm{Ns}}$ & $0.478^{* *}$ \\
\hline $\mathrm{Al}$ & & & & & & & & $0.026^{\mathrm{NS}}$ & $0.295^{\mathrm{Ns}}$ & $-0.166^{\mathrm{Ns}}$ & $0.375^{*}$ & $0.585^{* *}$ & $0.609^{* *}$ & $0.400^{* *}$ & $-0.442^{* *}$ & $-0.213^{\mathrm{Ns}}$ & $0.081^{\mathrm{Ns}}$ & $0.009^{\mathrm{Ns}}$ & $-0.262^{\mathrm{Ns}}$ & $0.287^{\mathrm{Ns}}$ & $-0.126^{\mathrm{Ns}}$ & $-0.295^{\mathrm{Ns}}$ \\
\hline S & & & & & & & & & $-0.731^{* *}$ & $0.810^{* *}$ & $-0.380^{*}$ & $-0.247^{\mathrm{Ns}}$ & $-0.183^{\mathrm{NS}}$ & $0.083^{\mathrm{NS}}$ & $0.517^{* *}$ & $0.376^{*}$ & $0.188^{\mathrm{Ns}}$ & $-0.298^{\mathrm{NS}}$ & $-0.495^{* *}$ & $0.127^{\mathrm{Ns}}$ & $-0.095^{\mathrm{Ns}}$ & $0.223^{\mathrm{NS}}$ \\
\hline Sand & & & & & & & & & & $-0.934^{* *}$ & $0.557^{* *}$ & $0.521^{* *}$ & $0.529 * *$ & $0.407^{* *}$ & $-0.568^{* *}$ & $-0.467^{* *}$ & $0.110^{\mathrm{NS}}$ & $0.127^{\mathrm{Ns}}$ & $0.355^{*}$ & $0.113^{\mathrm{Ns}}$ & $0.073^{\mathrm{Ns}}$ & $0.378^{*}$ \\
\hline Clay & & & & & & & & & & & $-0.438^{* *}$ & $-0.361^{*}$ & $-0.323^{*}$ & $-0.212^{\mathrm{NS}}$ & $0.587^{* *}$ & $0.269^{\mathrm{Ns}}$ & $0.086^{\mathrm{Ns}}$ & $-0.211^{\mathrm{Ns}}$ & $-0.507^{* *}$ & $-0.026^{\mathrm{Ns}}$ & $0.102^{\mathrm{Ns}}$ & $0.419^{* *}$ \\
\hline $\begin{array}{c}\text { SPR 0.0- } \\
0.10\end{array}$ & & & & & & & & & & & & $0.761^{* *}$ & $0.679 * *$ & $0.529 * *$ & $-0.502^{* *}$ & $-0.419 * * \quad-$ & $-0.096^{\mathrm{Ns}}-$ & $-0.011^{\mathrm{NS}}$ & $0.035^{\mathrm{NS}}$ & $-0.090^{\mathrm{Ns}}$ & $-0.112^{\mathrm{Ns}}$ & $0.053^{\mathrm{NS}}$ \\
\hline $\begin{array}{c}\text { SPR 0.11- } \\
0.20\end{array}$ & & & & & & & & & & & & & $0.871^{* *}$ & $0.606^{* *}$ & $-0.528^{* *}$ & $-0.399 * *$ & $-0.004^{\mathrm{Ns}}$ & $0.030^{\mathrm{Ns}}$ & $-0.062^{\mathrm{NS}}$ & $0.026^{\mathrm{Ns}}$ & $0.106^{\mathrm{Ns}}$ & $-0.147^{\mathrm{Ns}}$ \\
\hline $\begin{array}{c}\text { SPR 0.21- } \\
0.30 \\
\text { SPR }\end{array}$ & & & & & & & & & & & & & & $0.769^{* *}$ & $0.428 * *$ & $0.359 *$ & $0.183^{\mathrm{NS}}$ & $0.113^{\mathrm{NS}}$ & $-0.138^{\mathrm{NS}}$ & $-0.092^{\mathrm{NS}}$ & $0.084^{\mathrm{Ns}}$ & $-0.230^{\mathrm{Ns}}$ \\
\hline $\begin{array}{c}\text { SPR 0.31- } \\
0.40\end{array}$ & & & & & & & & & & & & & & & $-0.237^{\mathrm{NS}}$ & vs $-0.116^{\mathrm{Ns}}$ & $s \quad-0.345^{*}$ & $-0.154^{\mathrm{NS}}$ & $-0.210^{\mathrm{Ns}}$ & $-0.098^{\mathrm{NS}}$ & $0.005^{\mathrm{Ns}}$ & $-0,109^{\mathrm{Ns}}$ \\
\hline Prod. & & & & & & & & & & & & & & & & $0.719 * *$ & $0.282^{\mathrm{NS}}$ & $-0.238^{\mathrm{Ns}}$ & $-0.315^{*}$ & $-0.216^{\mathrm{Ns}}$ & $0.172^{\mathrm{Ns}}$ & $-0.237^{\mathrm{Ns}}$ \\
\hline NE & & & & & & & & & & & & & & & & & $0.183^{\mathrm{NS}}$ & $-0.367^{*}$ & $-0.149^{\mathrm{Ns}}$ & $0.101^{\mathrm{Ns}}$ & $-0.129^{\mathrm{Ns}}$ & $-0.092^{\mathrm{Ns}}$ \\
\hline Prot. & & & & & & & & & & & & & & & & & & $-0.089^{\mathrm{Ns}}$ & $-0.377^{*}$ & $-0.222^{\mathrm{NS}}$ & $0.179^{\mathrm{Ns}}$ & $-0.293^{\mathrm{Ns}}$ \\
\hline G & & & & & & & & & & & & & & & & & & & $0.457^{* *}$ & $0.323^{*}$ & $0.138^{\mathrm{Ns}}$ & $0.099^{\mathrm{Ns}}$ \\
\hline FGC & & & & & & & & & & & & & & & & & & & & $0.480^{* *}$ & $-0.248^{\mathrm{Ns}}$ & $0.529 * *$ \\
\hline $\mathrm{AA}$ & & & & & & & & & & & & & & & & & & & & & $-0.101^{\mathrm{NS}}$ & $0.305^{\mathrm{Ns}}$ \\
\hline SE & & & & & & & & & & & & & & & & & & & & & & $-0.128^{\mathrm{Ns}}$ \\
\hline
\end{tabular}

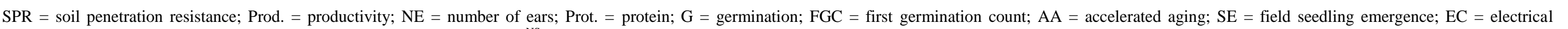
conductivity. **significant at $1 \%$ probability; *significant at $5 \%$ probability; ${ }^{\text {Ns: }}$, not significant. 
Regarding wheat technological quality, sulfur is essential for chlorophyll formation, being a constituent of gluten-forming proteins, in addition to stabilizing polymers of glutenin by sulfur bridges, which determine mass elasticity (Rodrigues \& Teixeira, 2010). This information is in accordance with the spatial distribution trend observed in sulfur and protein maps, which have the same spatial distribution trend (Figure 2).

The bottom of the maps of digital models of spatial distribution presented higher contents of $\mathrm{Ca}, \mathrm{Mg}, \mathrm{OM}, \mathrm{S}$, and $\mathrm{P}$, corresponding to a higher wheat productivity and number of ears $\mathrm{m}^{-2}$ (Figure 2). Productivity map is an important tool in decision-making and analysis of agricultural performance at a property level (Amado et al., 2009). In this sense, productivity had a significant and positive correlation with $\mathrm{OM}$ content since it is related to a higher soil water retention, increasing its availability to crops as the water deficit affects metabolism and decreases plant growth (Mondo et al., 2012).
Pearson's correlation analysis presented a positive correlation between productivity and clay content (Table 3) and a negative correlation between productivity and sand content (Figure 2). In the region with the highest clay content is the highest contents of $\mathrm{Ca}$ and $\mathrm{OM}$, leading to a higher productivity in this area since cation retention depends on clay content.

The significant correlation found between productivity and calcium and magnesium may be an important tool in wheat production since these subareas can be treated separately according to the most influential elements of productivity at low or high contents. The sampled areas reflect the behavior observed in the distribution of these elements, which could be observed by the visual analysis of the digital models. These results are in accordance with Vian et al. (2016), who observed that plant production is dependent on the interaction of soil chemical, physical, and biological factors, environmental factors, and the genetic characteristics of the cultivar, which can present distinct phenotypic characteristics. 


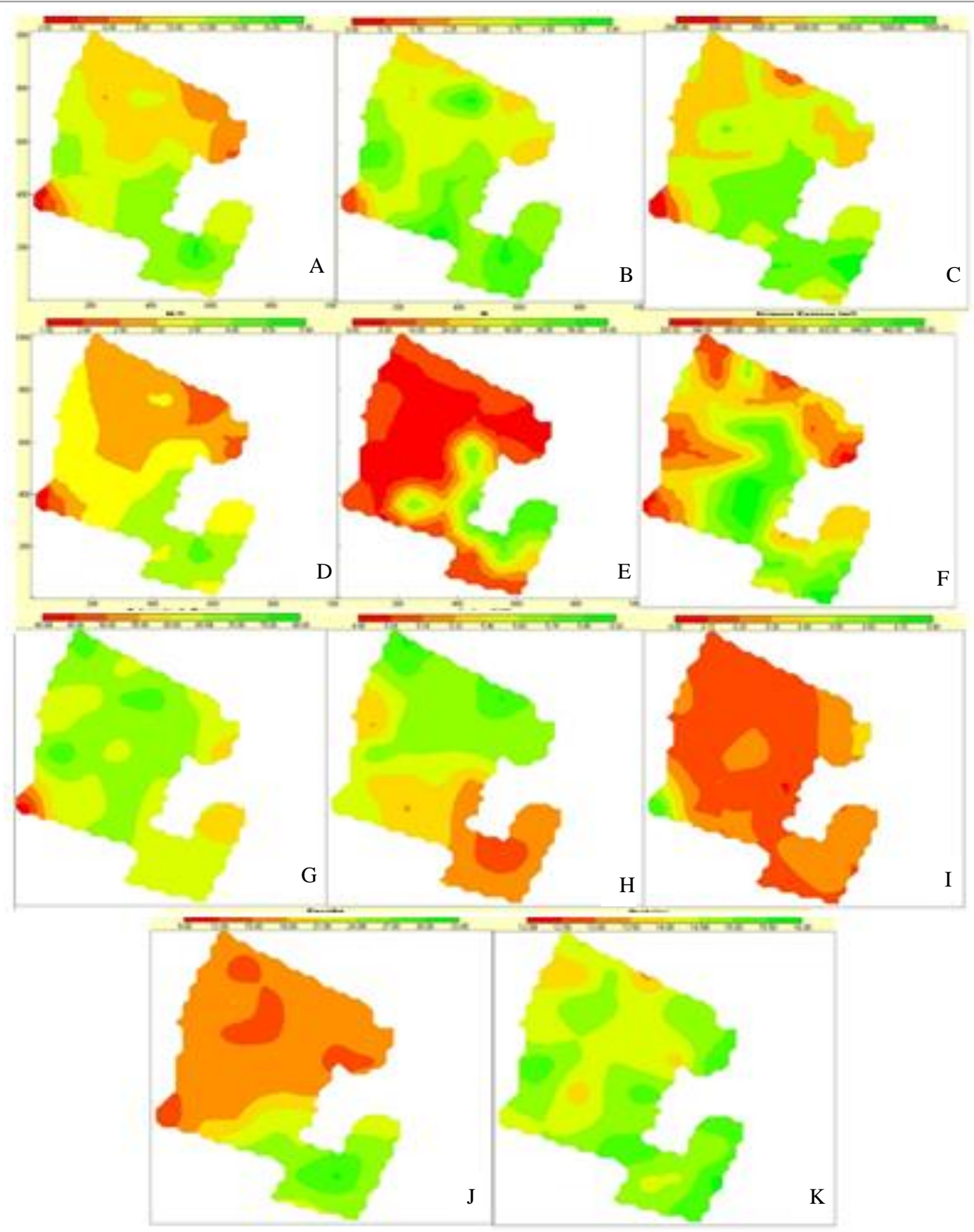

FIGURE 2. Spatial distribution maps of soil chemical properties, productivity, number of ears, and protein content of wheat seeds in the 2013 season. Ca (A); Mg (B); Wheat productivity (C); OM (D); P (E) ; Number of ears (F); Base saturation (G); SMP index (H); Aluminum(I); Sulfur (J); Protein(K). Lavras do Sul - RS (Brazil).

Spatial distribution maps showed that soil penetration resistance (Figure 3) might have influenced wheat seed productivity since in the region with the highest compaction in the three soil layers, a lower productivity was observed. Girardello et al. (2014) observed similar results in a study that aimed to assess the efficiency of chisel plows and their effect on soybean productivity. The lowest contents of phosphorus and calcium were observed in the region with the highest soil compaction (Figure 3), leading to a lower wheat productivity, i.e. soil compaction affected nutrient absorption and limited infiltration and redistribution of water. Similarly, Amado et al. (2009) found that the zone of lower productivity presented characteristics of higher penetration resistance, i.e. a higher soil compaction. 


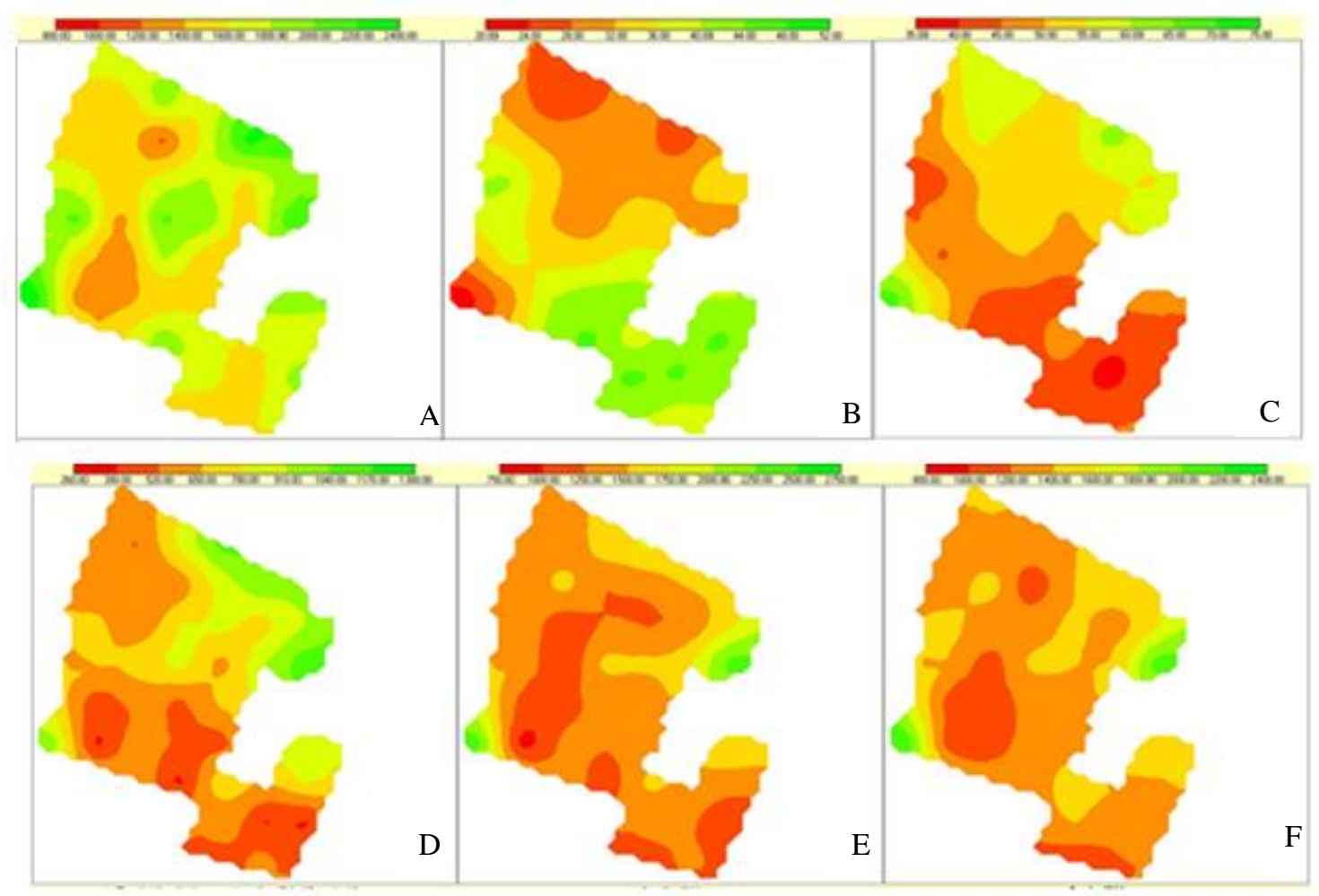

FIGURE 3. Spatial distribution maps of soil penetration resistance, clay, and sand. Soil penetration resistance; (A, B, C, D) Clay (E) ; Sand (F).Lavras do Sul - RS (Brazil).

\section{CONCLUSIONS}

The wheat cultivation area presents spatial variability of physiological seed quality although no correlation was observed with soil attributes.

Wheat productivity is strongly correlated with calcium and soil organic matter contents.

The analysis of spatial distribution maps of soil nutrients is a tool that can contribute to farmers' decision making in the management of crop fertilization aiming at improving seed productivity.

\section{REFERENCES}

Alves SM de F, Queiroz DM, Alcântara GR, Reis EF (2014) Variabilidade espacial de atributos físico-químicos do solo usando técnicas de análise de componentes principais e geoestatística. Bioscience Journal 30(3):22-30.

Amado TJC, Pes LZ, Lemainski CL, Schenato RB (2009) Atributos químicos e físicos de latossolos e sua relação com os rendimentos de milho e feijão irrigados. Revista Brasileira de Ciência do Solo 33(4):831-843. DOI: http://dx.doi.org/10.1590/S0100-06832009000400008

Andriotti JLS (2013) Fundamentos de estatística e geoestatística. São Leopoldo, Unisinos, 102p.

Bergamin AC, Vitorino ACT, Franchini JC, Souza CMA de, Souza FR de (2010) Compactação em um latossolo vermelho distroférrico e suas relações com o crescimento radicular do milho. Revista Brasileira de Ciência do Solo 34(3):681-691. DOI: http://dx.doi.org/10.1590/S010006832010000300009
Brasil. Ministério da Agricultura, Pecuária e

Abastecimento (2009) Regras para análise de sementes. MAPA, $395 \mathrm{p}$.

Cambardella CA, Moorman TB, Novak JM, Parkin TB, Karlen DL, Turco RF, Konopka AE (1994) Field-scale variability of soil properties in central Iowa soils. Soil Science Society of America Journal 58(5):1501-1511.

CQFS - Comissão de Química e Fertilidade do Solo (2016) Manual de calagem e adubação para os estados do Rio Grande do Sul e Santa Catarina. CQFS, 376p.

Dancey C, Reidy J (2013) Estatística sem matemática para psicologia. Porto Alegre, editora Penso, 5 ed. 608p.

Delouche JC, Baskin CC (1973) Accelerated aging techniques for predicting the relative storability of seed lots. Seed Science and Technology 1(1):427-52.

EMBRAPA - Empresa Brasileira de Pesquisa Agropecuária (2013) Sistema brasileiro de classificação de solos. EMBRAPA, 353p.

Gazolla-Neto A, Corrêa MF, Vergara R de O, Gadotti GI, Villela FA (2016) Spatial distribution of the chemical properties of the soil and of soybean yield in the field. Revista Ciência Agronômica 47(2):325-333. DOI: http://dx.doi.org/10.5935/1806-6690.20160038

Giotto L, Robaina AD, Sulzbach LA (2004) Agricultura de precisão com o sistema CR campeiro 7 - Manual do Usuário. Santa Maria, Universidade Federal de Santa Maria, 7 ed. 330p. 
Girardello VC, Amado TJC, Santi AL, Cherubin MR, Kunz J, Teixeira TG (2014) Resistência à penetração, eficiência de escarificadores mecânicos e produtividade da soja em latossolo argiloso manejado sob plantio direto de longa duração. Revista Brasileira de Ciência do Solo 38(4):1234-1244. DOI: http://dx.doi.org/10.1590/S010006832014000400020

Kramer LFM, Müller MML, Tormena CA, Genú AM, Michalovicz L, Vicensi M (2014) Atributos químicos do solo associados à produtividade do trigo em um talhão com diferentes potenciais produtivos. Revista Brasileira de Ciência do Solo 38(4):1190-1199. DOI: http://dx.doi.org/10.1590/S0100-06832014000400015

Lemos Filho LCA, Oliveira EL de, Faria MA de, Andrade LA de B (2008) Variação espacial da densidade do solo e matéria orgânica em área cultivada com cana-de-açúcar (Saccharum officinarum L.). Revista Ciência Agronômica 39(2):193-202.

Luz MLGS, Luz CAS, Gadotti GI (2013) Agricultura de precisão. Pelotas, Universidade Federal de Pelotas, 268p.

Machado AA, Conceição AR (2007) WinStat - Sistema de análise estatística para Windows. Pelotas, Universidade Federal de Pelotas.

Marcos Filho J, Cicero SM, Silva WR da (1987) Avaliação da qualidade das sementes. Piracicaba, Fundação de Estudos Agrários Luiz de Queiroz, 230p.

Mattioni NM, Schuch LOB, Villela FA (2011)

Variabilidade espacial da produtividade e da qualidade das sementes de soja em um campo de produção. Revista Brasileira de Sementes 33(4):608-615.

Mattioni NM, Schuch LOB, Villela FA (2013)

Variabilidade espacial e efeito de atributos químicos de um latossolo na população de plantas e produtividade da cultura da soja. Revista da FZVA 19(1):20-32.

Miguel PSB, Gomes FT, Rocha WSD da, Carvalho CA de, Oliveira AV de (2010) Efeitos tóxicos do alumínio no crescimento das plantas: mecanismos de tolerância, sintomas, efeitos fisiológicos, bioquímicos e controles genéticos. CES Revista 24(1):11-30.
Mondo VHV, Gomes Junior FG, Pinto TLF, Marchi JL de, Motomiya, AV de A, Molin JP, Cicero SM (2012) Spatial variability of soil fertility and its relationship with seed physiological potential in a soybean production area. Revista Brasileira de Sementes 34(2):193-201. DOI: http://dx.doi.org/10.1590/S0101-31222012000200002

OSU Seed Laboratory (2017) Oil, protein and moisture determination in seeds using NMR. OSU - Oregon State University. Available in:

http://seedlab.oregonstate.edu/sites/seedlab.oregonstate.ed u/files/nmr-brochure.pdf. Accessed: Mar 28, 2018.

Rodrigues MS, Corá JE, Fernandes C (2012) Spatial relationships between soil attributes and corn yield in notillage system. Revista Brasileira de Ciência do Solo 36(2):599-609. DOI: http://dx.doi.org/10.1590/S010006832012000200029

Rodrigues O, Haas JC, Costenaro ER (2011) Manejo de trigo para alta produtividade II: caracterização ontogenética. Revista Plantio Direto 20(125):10-13.

Rodrigues O, Teixeira MCC (2010) Bases ecofisiológicas para manutenção da qualidade do trigo. Passo Fundo, Embrapa Trigo, 84p.

Santi AL, Amado TJC, Cherubin MR, Martin TN, Pires JL, Flora LPD, Basso CJ (2012) Análise de componentes principais de atributos químicos e físicos do solo limitantes à produtividade de grãos. Pesquisa Agropecuária Brasileira 47(9):1346-1357.

Vian AL, Santi AL, Amado TJC, Cherubin MR, Simon DH, Damian JM, Bredemeier C (2016) Variabilidade espacial da produtividade de milho irrigado e sua correlação com variáveis explicativas de planta. Ciência Rural 46(3):464-471. DOI: http://dx.doi.org/10.1590/0103$8478 \mathrm{cr} 20150539$

Wilding LP, Dress LR (1983) Spatial variability and pedology. In: Wilding LP, Smeck, NE, Hall GF (eds). Pedogenesis and soil taxonamy: concepts and interactions. New York, Elsevier, p83-166. 